\title{
Complications of Pancreatic Cancer Resection
}

\author{
C.M. Halloran P. Ghaneh L. Bosonnet M.N. Hartley R. Sutton \\ J .P. Neoptolemos
}

Department of Surgery, Royal Liverpool University Hospital, Liverpool, UK

\section{Key Words}

Pancreatic cancer - Resection - Post-operative complications · Mortality $\cdot$ Morbidity $\cdot$ Re-operation rate

\begin{abstract}
Pancreatic cancer is a common cause of cancer death in the developed world. Currently, resection is the only chance of long-term survival. The post-operative mortality in nonspecialist centres often exceeds $20 \%$ but is around $6 \%$ or less in specialist centres. The overall complication rate even in specialist centres is $18-54 \%$. An analysis of eleven large series of pancreatic resections shows an incidence of common complications of $10.4 \%$ for fistula, $9.9 \%$ for delayed gastric emptying, $4.8 \%$ for bleeding, $4.8 \%$ for wound infection and $3.8 \%$ for intraabdominal abscess. The median hospital stay is 13-18 days in different series. The re-operation rate varies from 4 to $9 \%$ with a mortality rate of 23 to $67 \%$. Major complications are a significant factor in post-operative mortality, especially if they require re-operation. The use of octreotide or somatostatin to prevent complications is supported by several multicentre, double-blind, randomized controlled trials. The best way to improve outcome is to concentrate pancreatic cancer care in regional specialist centres.
\end{abstract}

Copyright @2002 S. Karger AG, Basel

\section{Introduction}

Adenocarcinoma of the pancreas is a common cause of cancer death in industrialized nations - currently the fourth most frequent in Europe [1,2]. Pancreatic cancer progresses unchecked for a long time before symptoms are recognized $[3,4]$ by which time the disease has usually reached an extent where cure is impossible. More than $80 \%$ of patients have positive regional lymph nodes or distant metastases at the time of diagnosis [5]. Resection provides the only prospect of 5-year survival although rarely cure [6-8]. The development of specialist pancreatic centres has dramatically improved the immediate outcome following resection for pancreatic cancer [9-17]. The role of adjuvant treatment for pancreatic ductal adenocarcinoma has yet to be fully established [18-21], but there are now some encouraging data from the ESPAC-1 trial [22]. There is no benefit from adjuvant chemoradiotherapy, but there may be benefit from 6 months' chemotherapy (5-FU and folinic acid) [22]. In order to improve on the overall 5 -year survival of all patients presenting with pancreatic adenocarcinoma of just $0.4 \%$ [23], it is imperative the respectability rates are improved and postoperative mortality is minimized.

Both the operative mortality and post-operative morbidity following pancreaticoduodenectomy has improved

\footnotetext{
Prof. John P. Neoptolemos

Department of Surgery, Royal Liverpool University Hospital

5th Floor UCD Building, Daulby Street

Liverpool L69 3GA (UK)

Fax +44 151706 4175, Fax +44 151706 5798, E-Mail j.p.neoptolemos@liv.ac.uk
} 
Table 1. Studies

\begin{tabular}{|c|c|c|c|c|c|c|}
\hline \multirow{2}{*}{$\begin{array}{l}\text { Study } \\
\text { (first author) }\end{array}$} & \multirow[t]{2}{*}{ Institution } & \multirow[t]{2}{*}{ Period } & \multirow{2}{*}{$\begin{array}{l}\text { Year } \\
\text { published }\end{array}$} & \multirow[t]{2}{*}{ Patients } & \multicolumn{2}{|c|}{ Mortality } \\
\hline & & & & & $\mathrm{n}$ & $\%$ \\
\hline Trede [13] & Mannheim & 1985-1999 & 1990 & 118 & 0 & 0 \\
\hline Matsumoto [48] & Yamanashi & $1983-1990$ & 1992 & 100 & 6 & 6 \\
\hline Hannoun $[46]^{1}$ & Hôpital St. Antoine, Paris & $1970-1990$ & 1993 & 223 & 20 & 9 \\
\hline Bakkevold [44] ${ }^{1}$ & Norway $^{2}$ & 1984-1997 & 1993 & 113 & 12 & $11^{3}$ \\
\hline Geer $[47]^{1}$ & Memorial Sloan-Kettering & $1983-1990$ & 1993 & 146 & 5 & $3^{3}$ \\
\hline Edge $[6]^{1}$ & $\mathrm{USA}^{2}$ & $1989-1990$ & 1993 & 223 & 13 & 6 \\
\hline Tsao $[45]^{1}$ & Lahey Clinic & 1979-1992 & 1994 & 106 & 6 & 6 \\
\hline Nitecki [42] ${ }^{1}$ & Mayo Clinic & $1981-1991$ & 1995 & 174 & 5 & 3 \\
\hline Neoptolemos $[11]^{1}$ & $\mathrm{UK}^{2}$ & $1976-1995$ & 1997 & 1,026 & 58 & 6 \\
\hline Yeo [16] & Johns Hopkins & 1990-1996 & 1997 & 650 & 9 & 1.4 \\
\hline Bottger [9] & Johannes Gutenberg, Mainz & $1985-1997$ & 1999 & 221 & 13 & 6 \\
\hline \multirow[t]{3}{*}{ Gouma [17] } & Amsterdam & 1983-1993 & & 163 & 8 & 4.9 \\
\hline & & 1993-1997 & 2000 & 149 & 2 & 1.3 \\
\hline & & $1997-1999$ & & 151 & 1 & 0.7 \\
\hline Büchler [49] & Bern & 1993-1999 & 2000 & 331 & 7 & 2 \\
\hline Neoptolemos ${ }^{1}$ & Liverpool & 1996-2001 & Unpubl. & 136 & 7 & 5 \\
\hline 1 Cancer cases only & & & & & & \\
\hline 2 Multicentre study & & & & & & \\
\hline 30-day mortality. & & & & & & \\
\hline
\end{tabular}

Table 2. Mortality following re-intervention for complications

\begin{tabular}{|c|c|c|c|c|c|c|c|c|c|}
\hline \multirow{3}{*}{$\begin{array}{l}\text { Study } \\
\text { (first author) }\end{array}$} & \multirow[t]{3}{*}{ Patients } & \multirow{2}{*}{\multicolumn{2}{|c|}{ Overall complications }} & \multirow{2}{*}{\multicolumn{2}{|c|}{ Re-operation }} & \multicolumn{4}{|c|}{ Mortality } \\
\hline & & & & & & \multicolumn{2}{|c|}{ post-operative } & \multicolumn{2}{|c|}{ overall } \\
\hline & & $\mathrm{n}$ & $\%$ & $\mathrm{n}$ & $\%$ & $\mathrm{n}$ & $\%$ & $\mathrm{n}$ & $\%$ \\
\hline Trede [13] & 118 & 21 & 18 & 7 & 6 & 0 & & 0 & \\
\hline Matsumoto [48] & 100 & 27 & 27 & 6 & 6 & 4 & 67 & 6 & 6 \\
\hline Yeo [16] & 650 & 266 & 41 & 26 & 4 & 9 & 35 & 9 & 1.4 \\
\hline Bottger [9] & 221 & 97 & 44 & 19 & 9 & 7 & 37 & 13 & 6 \\
\hline Büchler [49] & 331 & 127 & 38 & 13 & 4 & 3 & 23 & 7 & 3 \\
\hline Neoptolemos ${ }^{1}$ & 136 & 68 & 54 & 12 & 9 & 3 & 25 & 7 & 5 \\
\hline
\end{tabular}

by the development of specialist units with increased experience and the necessary resources for optimal care. Crist et al. [24] described over a 17-year period the gradual reduction of mortality from 11 to $2 \%$ and complications from 41 to $36 \%$. High through-put centres have convincingly reported low operative mortalities $[10,14,15$, 17, 24-36] (table 1). The incidence of post-operative complications, however, still remains high with overall com- plication rates of up to $60 \%[10,15,17,32,36-41]$ (table 2).

Complications may be stratified in several ways: medical vs. surgical, major vs. minor and early vs. late. The definitions are very imprecise, however, and there is little standardization in the way that these are reported. Hence it is very difficult to acquire an accurate picture of the nature and effect of the complications. It is noteworthy 
Table 3. Comparison of complication rate and hospital stay

\begin{tabular}{llccccc}
\hline $\begin{array}{l}\text { Study } \\
\text { (first author) }\end{array}$ & Patients & \multicolumn{2}{c}{ Overall complications } & & \multicolumn{2}{c}{ Hospital stay, days } \\
& & $\mathrm{n}$ & $\%$ & & median & range \\
\hline Trede [13] & 118 & 21 & 18 & & 16 & $10-44$ \\
Edge [6] & 223 & 96 & 43 & & 15 & $1-153$ \\
Yeo [16] & 650 & 266 & 41 & & 13 & $6-88$ \\
Bottger [9] & 221 & 97 & 44 & & 18 & $10-159$ \\
Büchler [49] & 331 & 127 & 38 & & 14 & $6-118$ \\
Gouma [17] & 163 & 97 & 60 & & 24 & $5-293$ \\
& 149 & 81 & 54 & & 18 & $7-222$ \\
& 151 & 62 & 41 & & 15 & $6-167$ \\
Neoptolemos & 136 & 68 & 54 & & 17 & $7-221$ \\
\hline
\end{tabular}

1 Cancer cases only.

Table 4. Complications following pancreatic resection (percentages in parentheses)

\begin{tabular}{|c|c|c|c|c|c|c|c|c|c|c|c|}
\hline & \multicolumn{11}{|c|}{ Study (first author) } \\
\hline & $\begin{array}{l}\text { Trede } \\
{[13]} \\
n=188\end{array}$ & $\begin{array}{l}\text { Matsumoto } \\
{[48]} \\
n=100\end{array}$ & $\begin{array}{l}\text { Hannoun } \\
{[46]^{1}} \\
n=223\end{array}$ & $\begin{array}{l}\text { Bakkevold } \\
{[44]^{1}} \\
n=113\end{array}$ & $\begin{array}{l}\text { Geer } \\
{[47]^{1}} \\
\mathrm{n}=146\end{array}$ & $\begin{array}{l}\text { Tsao } \\
{[45]^{1}} \\
n=106\end{array}$ & $\begin{array}{l}\text { Yeo } \\
{[16]} \\
n=650\end{array}$ & $\begin{array}{l}\text { Bottger } \\
{[9]} \\
n=221\end{array}$ & $\begin{array}{l}\text { Gouma } \\
{[50]^{1}} \\
n=312\end{array}$ & $\begin{array}{l}\text { Büchler } \\
{[49]} \\
n=331\end{array}$ & $\begin{array}{l}\text { Neoptolemos } \\
n=136\end{array}$ \\
\hline Abscess & $2(2)$ & $2(2)$ & $3(1)$ & $8(8)$ & $17(12)$ & $10(9)$ & $33(5)$ & - & $13(4)$ & $4(1)$ & $3(2)$ \\
\hline Haemorrhage & $6(5)$ & - & $20(9)$ & $16(15)$ & $8(5)$ & $4(4)$ & - & $7(3)$ & $37(12)$ & $12(4)$ & $7(5)$ \\
\hline Fistula & - & $16(16)$ & $34(15)$ & $4(4)$ & $2(1)$ & - & $92(14)$ & $18(8)$ & - & $7(2)$ & $12(9)$ \\
\hline Leak & $9(8)$ & - & - & $2(3)$ & - & $15(14)$ & - & $12(5)$ & $33(11)$ & - & - \\
\hline Wound infection & - & - & $13(6)$ & $4(4)$ & - & $2(2)$ & $66(10)$ & $5(2)$ & - & $13(4)$ & $15(11)$ \\
\hline Delayed gastric emptying & - & - & - & - & - & $15(14)$ & $124(19)$ & - & $45(30)$ & $54(16)$ & $5(4)$ \\
\hline Cholangitis & - & - & - & - & - & - & $31(5)$ & - & - & $7(2)$ & - \\
\hline Pancreatitis & - & - & - & - & - & - & $12(2)$ & - & - & - & - \\
\hline Sepsis & - & - & - & $4(4)$ & - & - & - & - & - & - & $1(1)$ \\
\hline Dehiscence & - & - & - & - & - & $1(1)$ & - & - & - & - & - \\
\hline Jejunal torsion & $1(1)$ & - & - & - & - & - & - & - & - & - & - \\
\hline Collection & - & - & - & - & - & - & - & $12(5)$ & - & - & - \\
\hline Other & - & - & $11(5)$ & $43(38)$ & - & $17(16)$ & $43(7)$ & $43(19)$ & - & $80(24)$ & $24(18)$ \\
\hline
\end{tabular}

1 Cancer cases only.

that although the morbidity varies from centre to centre, the median hospital stay is of a very similar order (13-18 days). This suggests that some centres with an average hospital stay are under-reporting their complications (table 3$)$.

\section{General Complications following Pancreatic Resection}

The relatively high incidence of post-operative complications refers to the complexity of surgery with multiple anastomoses of different types and the rather poor nutri- tional status and high background co-morbidity of the patient group [10, 32, 39, 41, 42]. Medical complications evoked as a consequence of surgery include cardiac problems (angina, infarction and arrhythmias), cardiovascular accidents (strokes), cardiorespiratory distress, renal dysfunction, pneumonia, thrombosis, pulmonary embolism, psychological disturbances and hepatic and metabolic dysfunction. The extent of surgery is correlated with the rise of medical complications [43, 44]. Post-operative complications contribute to the overall mortality [40, 44] despite the experience of specialist units $[43,44]$. In the medium to long term there is a risk of pancreatic exocrine insufficiency and post-operative weight loss for a variety 
Table 5. Summary of complications following pancreatic resection

\begin{tabular}{lcc}
\hline Complication & \multicolumn{2}{c}{ Total cases - all studies $(\mathrm{n}=2,456)$} \\
\cline { 2 - 3 } & $\mathrm{n}$ & $\%$ \\
\hline Abscess & 95 & 3.9 \\
Haemorrhage & 117 & 4.8 \\
Fistula & 256 & 10.4 \\
Wound infection & 118 & 4.8 \\
Delayed gastric emptying & 243 & 9.9 \\
Cholangitis & 38 & 1.5 \\
Pancreatitis & 12 & 0.5 \\
Sepsis & 5 & 0.2 \\
Dehiscence & 1 & 0 \\
Jejunal torsion & 1 & 0 \\
Collection & 12 & 0.5 \\
Other & 261 & 10.6 \\
\hline
\end{tabular}

of reasons [30, 45]. Late surgical complications include anastomotic stricture, bleeding gastritis, adhesions and marginal ulceration $[30,38,45]$. The post-operative medical complication rate is in the order of $4-19 \%[9,37,40$, 44-47].

\section{Surgical Complications following Pancreatic Resection}

Many of the post-operative complications respond to medical treatment, radiological intervention and endoscopic intervention without the need for surgical intervention. Complications that require operative re-intervention are associated with an increased mortality that ranges between 23 and $67 \%$ [9, 13, 16, 48, 49] (table 2).

\section{Intra-Abdominal Abscess}

Intra-abdominal abscess following pancreatic resection occurs in 1-12\% of patients [13, 44-50] (tables 4,5). Abscesses may contribute to septicaemia, which is found in $1-4 \%$ of patients $[39,44]$. Abscesses commonly arise from anastomotic leak at the pancreatoduodenostomy, the hepaticojejunostomy, the duodenojejunostomy, the gastrojejunostomy or the jejunojejunostomy and often herald as right subhepatic or left subdiaphragmatic collections [51,52]. A high-quality contrast-enhanced computed tomogram (CE-CT) examination is indicated whenever an intra-abdominal collection is suspected. The pre- ferred method of management is by percutaneous radiological drainage with the catheter inserted under CT control [53-56].

\section{Haemorrhage}

Post-operative haemorrhage occurs in $3-15 \%$ of patients following pancreatic resection $[9,13,44-47,49,50]$ (tables 4, 5). Reactionary haemorrhage (within the first 24 h) is the result of inadequate control at the time of surgery, a slipped ligature or bleeding from an anastomosis. In the latter case, management is conservative but immediate re-operation is usually required in the former cases. Stress ulceration is rare and usually can be managed medically and/or endoscopically [57].

Late haemorrhage (1-3 weeks following surgery) often has a more sinister underlying cause. It is commonly related to an anastomotic leak and secondary erosion of the retroperitoneal vasculature [58], with a mortality of 15$58 \%[59,60]$. Another sinister cause is a pseudoaneurysm. Investigations include CE-CT, endoscopy and selective angiography. If a bleeding point cannot be found endoscopically, then selective embolization of the source is undertaken providing that this can be identified by arteriography. Bleeding from a pancreatojejunostomy is particularly problematic with no clear evidence for the optimal re-interventional procedure. The choice lies between a completion total pancreatectomy and refashioning of the anastomosis after a limited resection of the jejunum and pancreas at the anastomosis. The clinical findings and the judgement of the surgeon determine the optimal procedure.

\section{Fistulae of the Pancreatointestinal Anastomosis}

There is no agreed definition of pancreatic fistula. The Heidelberg (formerly Berne) and Johns Hopkins units use a similar definition of pancreatic fistula, namely drainage of $>50 \mathrm{ml}$ of amylase-rich fluid per day from intraabdominal drains, on or after the 10th post-operative day $[41,49]$. Others define a pancreatic leak as the presence of drainage fluid that is rich in amylase ( $\geq 5$ times serum level) fluid or if the leak is radiologically demonstrable $[32,36]$. From these definitions it is clear that there is a considerable overlap between the use of the terms 'fistula' and 'leakage'. In our view these are arbitrary definitions and the terms fistula, leak, leakage and insufficiency are 
Table 6. Effect of octreotide (oct) or somatostatin (sms) administration for complications following pancreatic resection

\begin{tabular}{|c|c|c|c|c|c|c|c|c|c|c|c|c|c|}
\hline \multirow{3}{*}{$\begin{array}{l}\text { Study } \\
\text { (first author) }\end{array}$} & \multirow{3}{*}{$\begin{array}{l}\text { Patients } \\
\text { (cancer cases) }\end{array}$} & \multicolumn{4}{|c|}{ Pancreatic fistula } & \multicolumn{4}{|c|}{ Total complications } & \multicolumn{4}{|c|}{ Mortality } \\
\hline & & \multicolumn{2}{|c|}{ control } & \multicolumn{2}{|c|}{ oct/sms } & \multicolumn{2}{|c|}{ control } & \multicolumn{2}{|c|}{ oct $/ \mathrm{sms}$} & \multicolumn{2}{|c|}{ control } & \multicolumn{2}{|c|}{ oct/sms } \\
\hline & & $\mathrm{n}$ & $\%$ & $\mathrm{n}$ & $\%$ & $\mathrm{n}$ & $\%$ & $\mathrm{n}$ & $\%$ & $\mathrm{n}$ & $\%$ & $\mathrm{n}$ & $\%$ \\
\hline \multicolumn{14}{|l|}{ Octreotide } \\
\hline Büchler [83] ${ }^{1}$ & $246(120)$ & 53 & 44 & 28 & 22 & 67 & 55 & 40 & $32^{\mathrm{a}}$ & 7 & 6 & 4 & 3 \\
\hline Pederzoli [84] ${ }^{1}$ & $252(152)$ & 29 & 22 & 15 & 12 & 38 & 29 & 19 & $16^{\mathrm{a}}$ & 5 & 4 & 2 & 2 \\
\hline Friess $[88]^{1}$ & $247(0)$ & 29 & 23 & 13 & $11^{\mathrm{a}}$ & 37 & 30 & 20 & $16^{\mathrm{b}}$ & 1 & 1 & 2 & 2 \\
\hline Montorsi $[85]^{1}$ & $218(190)$ & 30 & 28 & 13 & $12^{\mathrm{a}}$ & 65 & 61 & 36 & $32^{\mathrm{a}}$ & 6 & 6 & 9 & 8 \\
\hline Lowy [86] & $110(105)$ & 11 & 21 & 16 & 28 & 13 & 25 & 19 & 33 & 0 & & 1 & 2 \\
\hline Yeo [87] & $211(176)$ & 10 & 9 & 11 & 11 & 36 & 34 & 42 & 40 & 0 & & 1 & 1 \\
\hline \multicolumn{14}{|l|}{ Somatostatin } \\
\hline Gouillat [89] ${ }^{1}$ & $75(71)$ & 10 & 27 & 4 & $11^{\mathrm{a}}$ & 12 & 32 & 5 & $13^{\mathrm{a}}$ & 1 & 3 & 2 & 5 \\
\hline $\begin{array}{l}\text { Multicentre } \\
\text { a } p<0.05 ; \text { b }\end{array}$ & ind, placebo-co & rolle & 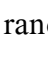 & l. & & & & & & & & & \\
\hline
\end{tabular}

interchangeable. The risk of 'pancreatic fistula' is reported as $1-16 \%[9,16,44,46-49]$, whereas the risk of a pancreatic anastomotic 'leak' is $3-14 \%[9,13,44,45$, 50].

The rates of fistulation at the biliary and intestinal-tointestinal anastomoses are less common. Biliary 'fistulation' is between 1 and $5 \%[13,37,40,46,47]$, biliary 'leakage' is $4 \%[10,16,32,39,41,45]$, gastric 'fistula' occurs in 1\% [46] and intestinal 'leak' occurs in 3\% [40]. Some groups [9, 44] refer to anastomotic insufficiency with frequencies of 2, 3 and $4 \%$ for pancreatic, gastric and biliary anastomoses, respectively. Matsumoto et al. [48] refer to an overall major fistula rate of $16 \%$ in addition to an overall minor fistula group of $12 \%$ (defined as fistulae that healed by conservative management). Interestingly, they were able to reduce their fistula rate of $26.4 \%$ using a two-layer method of anastomosis to $4.2 \%$ for a duct-tomucosa method of pancreatic anastomosis $(p<0.01)$.

The hospital mortality from a major pancreatic fistula may be high as $40 \%[9,14,16,61]$. Particular risk factors for breakdown of the pancreatic anastomosis are a soft parenchymal texture of the pancreatic remnant, the size of the remnant, the degree of pancreatic exocrine function and the anastomotic technique [51]. It is not clear which of the different anastomotic techniques produces optimal results [24, 30, 62-65]. Di Carlo et al. [66] have reported good results by occluding the pancreatic remnant duct with Neoprene ${ }^{\circledR}$. Ishikawa et al. [67] have suggested that pre-operative irradiation can decrease subsequent anastomotic leaks by decreasing overall pancreatic exocrine function. Our own unit has switched from an end-to-end dunking technique (with an external pancreatic stent) [68] to an end-to-side duct-to-mucosa technique (with an external pancreatic stent) with an improvement of results.

The management of a pancreatic fistula or leak depends on the individual patient. In the absence of peritonitis, sepsis or haemorrhage, conservative management should then be employed. Good monitoring is essential, but this may be achieved only if there is no adverse effect of the fistula output. High dependency monitoring may or may not be necessary, but usually not in the absence of other complications. The value of octreotide in the treatment of established pancreatic fistulae is not clear with studies showing conflicting data [69-73]. Whilst there may be a limited role for octreotide in the management of pancreatic fistula, there may be more to be gained in the presence of an intestinal fistula (uncommon in pancreatic surgery). Laparotomy is only indicated if there is an appreciable major complication that cannot be managed by other means, such as haemorrhage or if there is an uncontrollable fistula [61, 74-76].

\section{Delayed Gastric Emptying}

This is a frequent complication but with no generally agreed definition. A common definition of delayed gastric emptying is prolonged nasogastric aspiration beyond the 14th post-operative day and requiring either prokinetic agents or parentral nutrition before resolution $[32,36-38$, 
Fig. 1. Cost of pancreatic resection as a function of complications. Modified from Edge et al. [6].

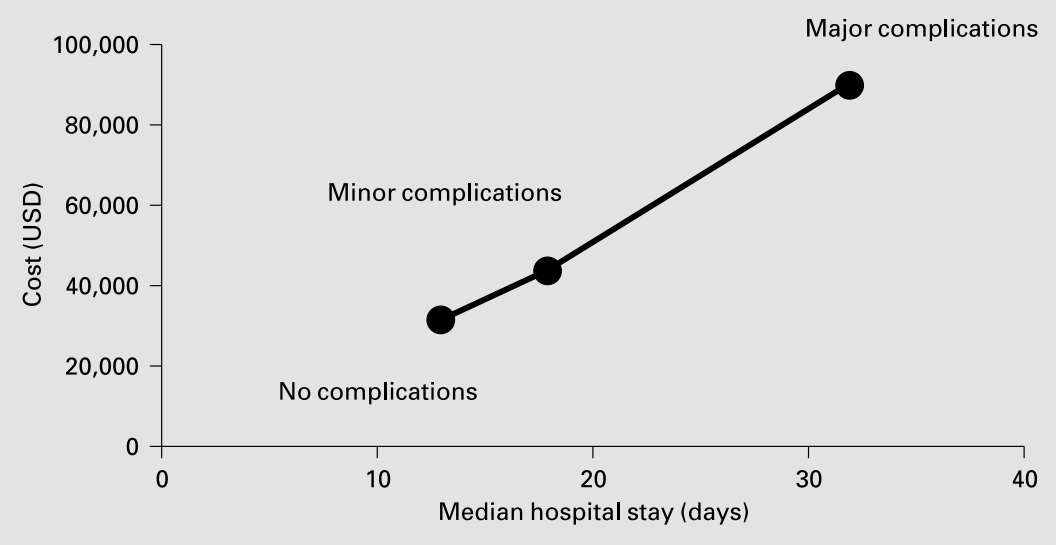

$41,45,49,51]$. The frequency is of the order of $14-30 \%$ of patients after pancreatic resection $[16,45,49,50]$, although it has been reported as high as 70\% [51]. Yeo et al. [77] have shown that delayed gastric emptying can be reduced by up to $37 \%$ following pancreatoduodenectomy with intravenous erythromycin. Although delayed gastric emptying almost invariably resolves with conservative treatment, operative correction is occasionally required [38]. There is some evidence to suggest that pylorus preservation increases the risk of delayed gastric emptying $[78,79]$. There is good evidence to show that delayed gastric emptying is related to the presence of intra-abdominal complications, especially that of a pancreatic leak $[32,45$, $78]$ and also extended radical surgery [8, 10, 80].

Other uncommon major complications include acute cholangitis, acute pancreatitis, small bowel obstruction, portal vein thrombosis and wound dehiscence (tables 4, 5).

\section{The Role of Prophylactic Octreotide in the Prevention of Complications following Pancreatic Resection}

Octreotide is the octapeptide analogue of somatostatin which is a powerful inhibitor of pancreatic secretion [81, 82]. There are several large prospective randomized trials investigating the effect of prophylactic octreotide in reducing post-operative complications, especially that of pancreatic fistula [83-87]. Four European multicentre, double-blind, randomized trials [83-85, 88] have shown that octreotide significantly reduces the overall complica- tions and two $[85,88]$ showed a specific reduction in the pancreatic fistula rate (table 6). Two later American studies $[86,87]$ did not show a benefit, although they used higher doses of octreotide (150 and $250 \mu \mathrm{g}$, respectively). These studies were not double-blinded or placebo-controlled [86, 87] and Yeo et al. [87] had a high exclusion rate. Gouillat et al. [89] showed that continuous somatostatin-14 infusion significantly reduced the pancreatic fistula rate and the total pancreatic stump-related complication rate also in a multicentre, double-blinded, placebocontrolled randomized trial.

\section{The Cost of Post-Operative Complications}

Health economic studies of pancreatic resection from the USA have reported an average length of stay of just over 20 days with an approximate cost of USD 1,000 per day [90-92]. Edge et al. [6] showed in a series of pancreatic resections at 26 American university hospitals a strong association between complications, length of hospital stay and cost (fig. 1). Surgeons performing less than four resections a year had significantly more complications than those performing more resections. High-volume centres are able to achieve a dramatic reduction in mortality over low-volume centres [11, 17, 23, 91, 93-97] (fig. 2) and it follows that regionalization of the service to high-volume providers should reduce complications. 
Fig. 2. Impact of high-volume centres on mortality [11, 17, 23, 91, 93-97].

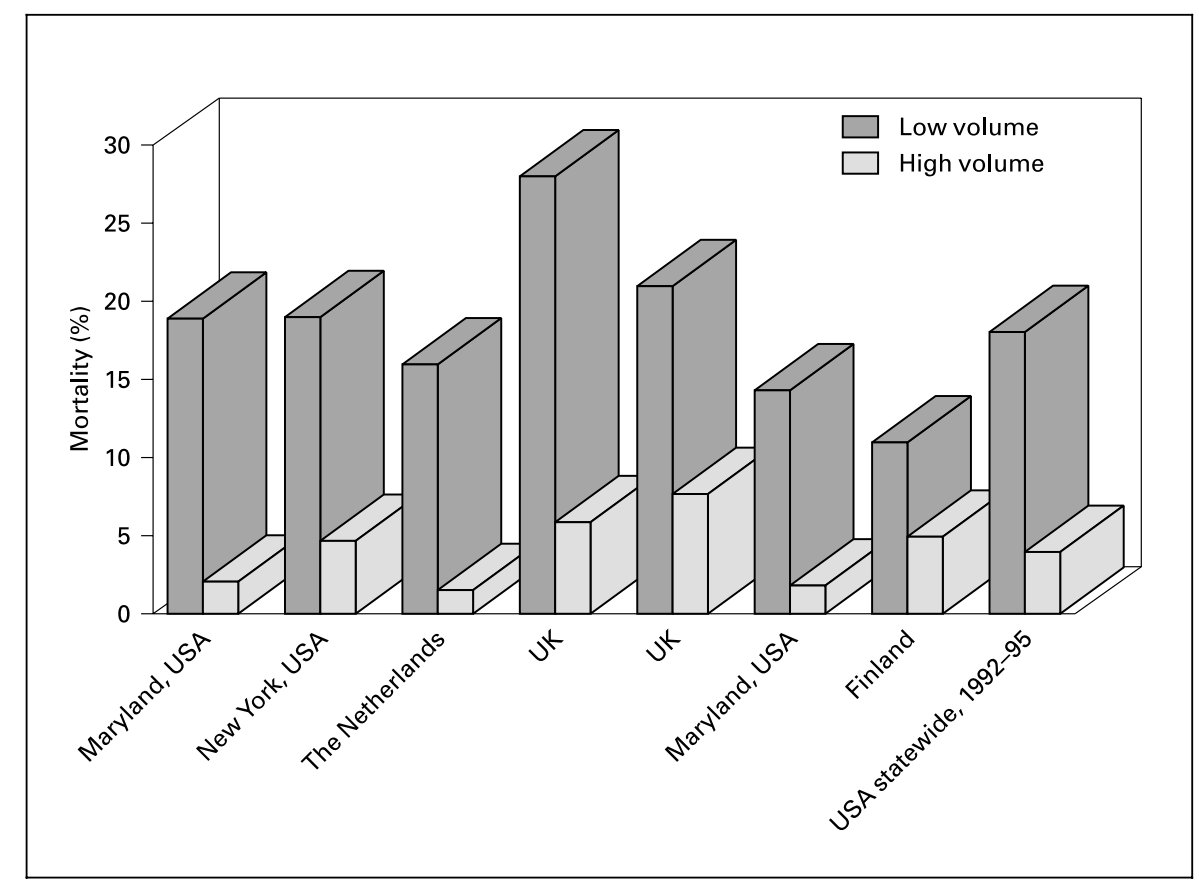

\section{Conclusions}

Although mortality following pancreatic resection has fallen sharply in recent years, the overall complication rate is still high with a wide variation in the standard of reporting from the literature. Some series report only major surgical complications since the most of re-interventions and subsequent mortality come from this group.
Nevertheless, medical and minor conditions still have an impact on overall hospital stay and accumulated cost for the procedure. Whilst major complications add $190 \%$ to the overall cost compared to no complications, minor complications will also increase cost by $40 \%$. By centralization and referral to high through-put specialist centres, it is hoped the rate of complications will eventually fall.

\section{References}

1 Parker SL, Tong T, Bolden S, Wingo PA: Cancer statistics. CA Cancer J Clin 1997;47:5-27.

2 Gudjonsson B: Cancer of the pancreas. Fifty years of surgery. Cancer 1987;60:2284-2303.

3 Hermanenk P, Gall FP, Wittlund CH: Pancreatic ductal adenocarcinoma surgery. Int $\mathrm{J}$ Pancreatol 1994;16:302-304.

4 Pour PM, Egams H, Takiyama Y: Patterns of growth and metastases of induced pancreatic cancer in relation to prognosis and its clinical implications. Gastroenterolgy 1991;100:529.

5 Cubilla AG, Fortner J, Fitzgerald PJ: Lymph node involvement in carcinoma head of pancreas. Cancer 1978;41:880-887.

6 Edge SB, Schmeigher JR, Rosenlif LF, Willheim MC: Pancreatic cancer resectional outcomes in American university centers 19881990. Cancer 1993; 71:3502-3508.
7 Conlon KC, Klimstra DS, Brennan MF: Longterm survival after curative resection for pancreatic ductal adenocarcinoma: Clinical-pathological analysis of 5-year survivors. Ann Surg 1996;223:237-239.

8 Yeo CJ, Cameron JL, Sohn TA, Coleman J, Sauter PK, Hruban RH, Pitt HA, Lillemoe KD: Pancreatoduodenectomy with or without extended retroperitoneal lymphadectomy for periampullary adenocarcinoma: Comparison of morbidity and mortality and short-term exposure. Ann Surg 1999;229:613-622.

9 Bottger T, Junginger T: Factors influencing morbidity and mortality after pancreaticoduodenectomy: Critical analysis of 221 resections. World J Surg 1999;23:164-172.
10 Cameron JL, Pitt HA, Yeo CJ, Lillemoe KD Kaufman HS, Coleman J: One hundred and forty-five consecutive pancreatoduodenectomies without mortality. Ann Surg 1993;217: 430-435.

11 Neoptolemos JP, Russell RC, Bramhall S, Theis B: Low mortality following resection for pancreatic and periampullary tumours in 1,026 patients: UK survey of specialist pancreatic units. UK pancreatic group. Br J Surg 1997;84: 1370-1376.

12 Russell RC: Surgical resection for cancer of the pancreas. Baillières Clin Gastroenterol 1990;4 889-916.

13 Trede M, Schwall G, Saeger HD: Survival after pancreatoduodenectomy. 118 consecutive resections without an operative mortality. Ann Surg 1990;211:447-458. 
14 Trede M, Saeger HD, Schwall G, Rumstadt B: Resection of pancreatic cancer. Surgical achievements. Langenbecks Arch Surg 1998; 383:121-128.

15 Tsuchida R, Tsunoda T, Ishida T, Saitoh Y: Resection for pancreatic cancer: The Japanese experience. Baillières Clin Gastroenterol 1990; 4:931-939.

16 Yeo CJ, Cameron JL, Sohn TA, Lillemoe KD, Pitt HA, Talamini MA, Hruban RH, Ord SE, Sauter PK, Coleman J, Zahurak ML, Grochow LB, Abrams RA: Six hundred and fifty consecutive pancreaticoduodenectomies in the 1990s. Ann Surg 1997;226:248-260.

17 Gouma DJ, van Geenen RC, van Guilk TM, de Haan RJ, de Wit LT, Busch OR, Obertop H Rates of complications and death after pancreatoduodenectomy: Risk factors and the impact of hospital volume. Ann Surg 2000;232. 786-795.

18 Bramhall SR, Neoptolemos JP: Adjuvant chemotherapy in pancreatic cancer. Int J Pancreatol 1997;21:59-63.

19 Büchler M, Friess H, Schultheiss KH, Glebhardt $\mathrm{C}$, Klubel R, Muhrer KH, Winklemann M, Wagener T, Klapdor R, Kaul M: A randomised controlled trial of adjuvant immunotherapy (murine monoclonal antibody 493/32) in resectable pancreatic cancer. Cancer 1991;68: 1507-1512.

20 Friess H, Büchler MC, Beglinger C, Weber A, Kunz J, Fritsch K, Dennler HJ, Beger HG: Low-dose octreotide treatment is not effective in patients with advanced pancreatic cancer. Pancreas 1993;8:540-545.

21 Friess H, Büchler MC, Kruger M, Beger HG: Treatment of duct carcinoma of the pancreas with the LH-RH analogue Buserelin. Pancreas 1992; 7:516-521.

22 Neoptolemos JP, Dunn JA, Moffitt DD, Almond J, Link K, Beger H, Bassi C, Falconi M, Pederzoli P, Dervenis C, Fernandez-Cruz L, Lacaine F, Pap A, Spooner D, Kerr DJ, Friess H, Büchler M: Adjuvant chemoradiotherapy and chemotherapy in resectable pancreatic cancer: A randomised controlled trial. Lancet 2001;358:1576-1585.

23 Northern and Yorkshire Cancer Registry and Information Service: Cancer treatment policies and their effect on survival - Pancreas. NYCRIS 2000; section 4.3:19.

24 Crist DW, Sitzmann JV, Cameron JL: Improved hospital morbidity, mortality and survival after the Whipple procedure. Ann Surg 1987;206:358-365.

25 Sener SF, Fremgen A, Menck HR, Winchester DP: Pancreatic cancer: A report of treatment and survival trends for 100,313 patients diagnosed from 1985 to 1995 , using the Nationa Cancer Database. J Am Coll Surg 1999;189:17.

26 Howard JM: Pancreaticoduodenectomy: Forty-one consecutive Whipple resections without an operative mortality. Ann Surg 1968;168: 629-640.

27 Trede M: The surgical treatment of pancreatic carcinoma. Surgery 1985;97:28-35.

Complications of Pancreatic Cancer

Resection
28 Braasch JW, Rossi RL: Pyloric preservation with the Whipple procedure. Surg Clin North Am 1985;65:263-271.

29 Grace PA, Pitt HA, Tompkins RK, Den Besten L, Longmire WP: Decreased morbidity and mortality after pancreatoduodenectomy. Am J Surg 1986;151:141-149.

30 Braasch JW, Deziel DJ, Rossi RL, Watkins E $\mathrm{Jr}$, Winter PF: Pyloric and gastric preserving pancreatic resection. Experience with 87 patients. Ann Surg 1986;204:411-418.

31 Pelligrini CA, Heck CF, Raper S, Way LW: An analysis of the reduced morbidity and mortality rates after pancreaticoduodenectomy. Arch Surg 1989;124:778-781.

32 Miedema BW, Sarr MG, van Heerden JA, Nagorney DM, McIlrath DC, Listrup D: Complications following pancreaticoduodenectomy. Current management. Arch Surg 1992;127: 945-950.

33 Wade TP, Radford DM, Virgo KS, Johnson FE: Complications and outcome in the treatment of pancreatic adenocarcinoma in the United States veterans. J Am Coll Surg 1994; 179:38-48.

34 Friess H, Uhl W, Beger HG, Büchler MW: Surgical treatment of pancreatic cancer. Dig Surg 1994;11:378-386.

35 Van Heerden JA: Pancreatic resection for carcinoma of the pancreas: Whipple versus total pancreatectomy - An institutional perspective. World J Surg 1984;8:880-888.

36 Cunningham JD, Weyant MT, Levitt M, Brower ST, Aufses AH: Complications requiring reoperation following pancreatectomy. Int J Pancreatol 1998;24:23-29.

37 Fernandez-del Castillo C, Rattner DW, Warshaw AL: Standards for pancreatic resection in the 1990s. Arch Surg 1995;130:295-300.

38 Watanapa P, Williamson RCN: Resection of the pancreatic head with or without gastrectomy. World J Surg 1995; 19:403-409.

39 Reinders ME, Allema JH, van Guilk TM, Karsten TM, de Wit LT, Verbeek PCM, Rauws EJ, Gouma DJ: Outcome of microscopic nonradical, subtotal pancreatoduodenectomy (Whipple resection) for treatment of pancreatic head tumours. World J Surg 1995;19:410-415.

40 Sperti C, Pasquali C, Piccoli A, Pedrazzoli S: Survival after resection for ductal adenocarcinoma of the pancreas. Br J Surg 1996;83:625631.

41 Talamini MA, Moesinger MD, Pitt HA, Sohn TA, Hruban RH, Lillemoe KD, Yeo CJ, Cameron JL: Adenocarcinoma of the ampulla of Vater. A 28-year experience. Ann Surg 1997; 225:590-600.

42 Nitecki SS, Sarr MG, Colby TV, van Heerden JA: Long-term survival after resection for ductal adenocarcinoma of the pancreas. Ann Surg 1995;221:59-66.

43 Gilsdorf RB, Spanos P: Factors influencing morbidity and mortality in pancreatoduodenectomy. Ann Surg 1973;177:332-337.

44 Bakkevold KE, Kambestd B: Morbidity and mortality after radical and palliative pancreatic cancer surgery. Risk factors influencing the short-term results. Ann Surg 1993;217:356368.
45 Tsao JI, Rossi RL, Lowell JA: Pylorus preserving pancreatoduodenectomy. Is it an adequate cancer operation. Arch Surg 1994;129:405412.

46 Hannoun L, Riberio J, Norlinger B, Elriwini M, Tiret E, Parc R: A report of forty-four instances of pancreatoduodenal resection in patients more than seventy years of age. Surg Gynecol Obstet 1993;177:556-560.

47 Geer RJ, Brennan MF: Prognostic indicators for survival after resection of pancreatic adenocarcinoma. Am J Surg 1993;165:68-73.

48 Matsumoto Y, Fujii H, Miura K, Inoue S, Sekikawa T, Aoyama H, Ohnishi N, Sakai K, Suda $\mathrm{K}$ : Successful pancreatojejunual anastomosis for pancreatoduodenectomy. Surg Gynecol Obstet 1992;175:555-562.

49 Büchler M, Friess H, Wagner M, Kulli C, Wagener $\mathrm{V}$, Z'graggen $\mathrm{K}$ : Pancreatic fistula after pancreatic head resection. Br J Surg 2000;87: 883-889.

50 Gouma DJ, Nieveen van Dijkum EJM, Obertop H: Pancreatic cancer: Matters for debate. The standard diagnostic work-up and surgical treatment of pancreatic head tumours. Eur J Surg Oncol 1999;25:113-123.

51 Berberat PO, Friess H, Kleeff J, Uhl W, Büchler MW: Prevention and treatment of complications in pancreatic cancer surgery. Dig Surg 1999;16:327-336.

52 Yeo CJ, Cameron JL, Lillemoe KD, Sitzmann JV, Hruban RH, Goodman SN, Dooley WC, Coleman J, Pitt HA: Pancreatoduodenectomy for cancer of the head of the pancreas. Ann Surg 1995;221:721-733.

53 Szentes MJ, Traverso LW, Kozarek RA, Freeny PC: Invasive treatment of pancreatic fluid collections with surgical and nonsurgical methods. Am J Surg 1991;161:600-605.

54 Freeny PC: Percutaneous management of pancreatic fluid collections. Baillières Clin Gastroenterol 1992;6:259-272.

55 Oglevie SB, Casola G, van Sonnenberg E D'Agostino HB, Olaoide R, Fundell L: Percutaneous abscess drainage: Current applications for critically ill patients. J Int Care Med 1994;9: 191-206.

56 Van Sonnenberg E, Wittich GR, Goodacre BW, Casola G, D'Agostino HB: Percutaneous abscess drainage: Update. World J Surg 2001; 25:362-369.

57 Rumstadt B, Schwab M, Korth P, Samman M, Trede M: Haemorrhage after pancreatoduodenectomy. Ann Surg 1998;227:236-241.

58 Brodsky JT, Turnbull AD: Arterial haemorrhage after pancreatoduodenectomy. The 'sentinal bleed'. Arch Surg 1991;126:1037-1040.

59 Van Berge Henegouwen MI, Allema JH, van Guilk TM, Verbeek PCM, Obertop H, Gouma DJ: Delayed massive haemorrhage after pancreatic and surgery. Br J Surg 1995;82:15271531

60 Shankar R, Russell RCG: Haemorrhage in pancreatic disease. Br J Surg 1989;76:863-866.

61 Cullen JJ, Sarr MG, Ilstrup DM: Pancreatic anastomotic leak after pancreaticoduodenectomy: Incidence, significance and management. Am J Surg 1994;168:295-298. 
62 Greene BS, Loubeau JM, Peoples JB, Elliott DW: Are pancreatic anastomoses improved by duct-to-mucosa sutures? Am J Surg 1991;161: 45-49.

63 Marcus SG, Cohen H, Ranson JH: Optimal management of the pancreatic remnant after pancreaticoduodenectomy. Ann Surg 1995; 221:635-645.

64 Grace PA, Pitt HA, Longmire WP: Pancreatoduodenectomy with pylorus preservation for adenocarcinoma of the head of pancreas. $\mathrm{Br} \mathrm{J}$ Surg 1986;73:647-650.

65 Sikora SS, Posner MC: Management of the pancreatic stump following pancreaticoduodenectomy. Br J Surg 1995;82:1590-1597.

66 Di Carlo V, Chiesa R, Pontiroli A, Carlucci M, Staudacher C, Zerbi A, Cristallo M, Braga M, Pozza G: Pancreatoduodenectomy with occlusion of the residual stump by Neoprene injection. World J Surg 1989; 13:105-111.

67 Ishikawa $\mathrm{O}$, Ohigashi $\mathrm{H}$, Imaoka S, Teshima $\mathrm{T}$, Inoue T, Sasaki Y, Iwanga T, Nakaizumi A: Concomitant benefit of preoperative irradiation in preventing pancreas fistula formation after pancreatoduodenectomy. Arch Surg 1991;126:885-889.

68 Williams JG, Bramhall SR, Neoptolemos JP Purse-string pancreatico-jejunostomy following pancreatic resection. Dig Surg 1997;14: 183-186.

69 Torres AJ, Landa JI, Moreno-Azcoita M, Arguello JM, Silecchia G, Castro J, HernandezMerlo F, Jover JM, Moreno-Gonzales E, Bailbrea JL: Somatostatin in the management of gastrointestinal fistulas. A multicentre trial. Arch Surg 1992;127:97-99.

70 Sancho JJ, di Costanzo J, Nubiola P, Larrad A, Beguiristain A, Roqueta F, Franch G, Oliva A Gubern JM, Sitges-Serra A: Randomised double-blind placebo-controlled trial of early octreotide in patients with post-operative enterocutaneous fistula. Br J Surg 1995;82:638-641.

71 Nubiola P, Badia JM, Martinez-Rodenas F, Gill MJ, Segura M, Sancho JJ, Sitges-Serra A: Treatment of 27 postoperative enterocutaneous fistulas with long half-life somatostatin analogue SMS 201-995. Ann Surg 1989;210: 56-58.

72 Bassi C, Falconi M, Salvia R, Caldiron E, Butturini G, Pederzoli P: Role of octreotide in the treatment of external pancreatic pure fistula: A single-institution prospective experience. Langenbecks Arch Surg 2000;385:10-13.

73 Alvarez C, McFadden DW, Reber HA: Complicated enterocutaneous fistula: Failure of octreotide to improve healing. World J Surg 2000;24:533-537.

74 Sato N, Yamaguchi K, Chijiiwa K, Tanaka M Risk analysis of fistula after pancreatic head resection. Arch Surg 1998;133:1094-1098.
75 Van Berge Henegouwen MI, de Witt LT, van Guilk TM, Obertop H, Gouma DJ: Incidence, risk factors and treatment of pancreatic leakage after a pancreatoduodenectomy: Drainage versus resection of pancreatic remnant. J Am Coll Surg 1997;185:18-24.

76 Farley DR, Schwall G, Trede M: Completion pancreatectomy for complications after pancreatoduodenectomy. Br J Surg 1996;83:176179.

77 Yeo CJ, Barry K, Sauter PK, Sostre S, Lillemoe KD, Pitt HA, Cameron JL: Erythomycin accelerates gastric emptying after pancreatoduodenectomy. Ann Surg 1993;218:229-238.

78 Van Berge Henegouwen MI, van Guilk TM, De Witt LT, Allema JH, Rauws EJ, Obertop H, Gouma DJ: Delayed gastric emptying after standard pancreatoduodenectomy versus pylorus preserving pancreatoduodenectomy: An analysis of 200 consecutive patients. J Am Coll Surg 1997; 185:373-379.

79 Zerbi A, Balzano G, Patuzzo R, Calori G, Braga M, Dicarlo V: Comparison between pylorus preserving and Whipple pancreatoduodenectomy. Br J Surg 1995;82:975-979.

80 Pedrazzoli S, Di Carlo V, Dionigi R, Mosca F, Pederzoli P, Pasquali C, Kloppel G, Dhaene K, Michelassi F: Standard versus extended lymphadenectomy associated with pancreatoduodenectomy in the surgical treatment of adenocarcinoma of the head of the pancreas: A multicentre, prospective, randomised study. Lymphadectomy Study Group. Ann Surg 1998;28: 508-517.

81 Creutzfeldt W, Lankisch PG, Folsch UR: Inhibition by somatostatin of pancreatic juice and enzyme secretion and gallbladder contraction in man induced by secretin and cholecystokinin-pancreozymin administration. Dtsch Med Wochenschr 1975;100:1135-1138.

82 Raptis S, Schlegel W, Lehmann E, Dollinger $\mathrm{HC}$, Zoupas C: Effects of somatostatin on the exocrine pancreas and the release of duodenal hormones. Metabolism 1978;27:3121-3128.

83 Büchler M, Friess H, Klempa I, Hermanek P, Sulkowski U, Becker H, Schafmayer A, Baca I, Lorenz D, Meister R, Kremer B, Wagner P, Witte J, Zurmayer EL, Saeger HD, Rieck B, Dollinger P, Glaser K, Teichmann R, Konradt J, Gaus W, Dennler HJ, Wetzel D, Beger HG: Role of octreotide in the prevention of postoperative complications following pancreatic resection. Am J Surg 1992;163:125-131.

84 Pederzoli P, Bassi C, Falconi M, Camboni MG and the Italian Study Group: Efficacy of octreotide in the prevention of complications of elective pancreatic surgery. Br J Surg 1994;81: 265-270.

85 Montorsi M, Zago M, Mosca F, Capussotti L, Zotti E, Ribotta G, Fegiz G, Fissi S, Roviaro G, Peracchia A, Pivi M, Perego R, Pezzuoli G: Efficacy of octreotide in the prevention of pancreatic fistula after elective pancreatic resections: A prospective, controlled, randomised clinical trial. Surgery 1995;117:26-31.
86 Lowy AM, Lee JE, Pisters PWT, Davidson BS, Fenoglio CJ, Stanford P, Jinnah R, Evans DB: Prospective, randomised trial of octreotide to prevent pancreatic fistula after pancreatoduodenectomy for malignant disease. Ann Surg 1997;226:632-641.

87 Yeo CJ, Cameron JL, Lillemoe KD, Sauter PK, Coleman J, Sohn TA, Campbell KA, Choti MA: Does prophylactic octreotide decrease the rates of pancreatic fistula and other complications after pancreatoduodenectomy? Results of a prospective randomised placebo-controlled trial. Ann Surg 2000;232:419-429.

88 Friess H, Beger HG, Sulkowski U, Becker H, Hofbauer B, Dennler HJ, Büchler MW: Randomised controlled multicentre study of the prevention of complications by octreotide in patients undergoing surgery for chronic pancreatitis. Br J Surg 1995;82:1270-1273.

89 Gouillat C, Chipponi J, Baulieux J, Partensky C, Saric J, Gayet B: Randomised controlled multicentre trial of somatostatin infusion after pancreatoduodenectomy. Br J Surg 2001;88: 1456-1462.

90 Schaefer CJ: Cost and outcome of the Whipple procedure. Ann Surg 1995;222:211-212.

91 Gordon TA, Burleyson GP, Tielsch JM, Cameron JL: The effect of regionalization on cost and outcome for one general high-risk surgical procedure. Ann Surg 1995;221:43-49.

92 Rosenberg 1, MacNeil P, Turcotte L: Economic evaluation of the use of octreotide for prevention of complications following pancreatic resection. J Gastrointest Surg 1999;3:225-232.

93 Gordon TA, Bowman HM, Tielsch JM, Bass EB, Burleyson GP, Cameron JL: Statewide regionalization of pancreaticoduodenectomy and its effect on in-hospital mortality. Ann Surg 1998;228:71-78.

94 Lieberman MD, Kilburn H, Lindsey M, Brennan MF: Relation of preoperative deaths to hospital volume among patients undergoing pancreatic resection for malignancy. Ann Surg 1995;222:638-645.

95 Bramhall SR, Allum WH, Jones AG, Allwood A, Cummins C, Neoptolemos JP: Treatment and survival in 13,560 patients with pancreatic cancer, and incidence of the disease, in the West Midlands: An epidemiological study. Br J Surg 1995;84:111-115.

96 Sand J, Nordback I: Should we concentrate pancreatoduodenectomies to fewer hospitals in Finland? Abstract. Finnish Surgical Society Annual Meeting. 1996;17:45.

97 Birkmeyer JD, Finlayson SRG, Tosteson ANA, Sharp SM, Warshaw AL, Fisher ES: Effect of hospital volume on in-hospital mortality with pancreaticoduodenectomy. Surgery 1999;125: 250-256. 